\title{
COLISTIMETHATE AS A CAUSE OF POSTOPERATIVE APNOEA
}

\author{
Howard L. Zauder, M.D., Ph.D., NeTl Barton, M.D., EdWard J. BenNetT, M.B., B.S., \\ AND JOHN LORE, M.B., B.S., D.A., F.F.A.R.C.S. ${ }^{*}$
}

The NEURomuscular bLOCKING ACTION of several commonly employed antibiotics is now well established. ${ }^{1}$ Respiratory arrest in humans has been attributed to intraperitoneal installation of neomycin, ${ }^{2,3}$ kanamycin, ${ }^{4}$ and streptomycin, ${ }^{5,6}$ to intraplueral neomycin, ${ }^{7}$ and to streptomycin ${ }^{6}$ and intravenous kanamycin. ${ }^{8}$ In several isolated instances, neostigmine-resistant curarization occurred in patients whose bowel had been prepared for surgery with oral neomycin.,10 Respiratory failure was observed in an unanaesthetized infant following six oral doses of $100 \mathrm{mg}$. of neomycin. ${ }^{11}$ While colistin sulfate is an effective non-depolarizing blocking agent, the sodium salt of the methane sulfonate derivative of colistin is devoid of neuromuscular blocking activity. ${ }^{12}$ Nevertheless two cases of apnoea have been described following the administration of large doses of colistimethate sodium. ${ }^{13,14}$ This report describes a case of prolonged postoperative apnoea resulting from the parenteral administration of this polysaccharide antibiotic.

\section{CASE REPORT}

A 49-year-old white female was hospitalized with a history of left flank pain of two to three days' duration. Prior to admission she had had intermittent elevations of temperature which had been treated with $2 \mathrm{gm}$. chloramphenicol. When the symptoms did not remit she sought medical aid.

During the previous 14 years the patient had suffered intermittent attacks of pyelonephritis. In 1957 she underwent parathyroidectomy for carcinoma. At that time she had symptoms referable to hypercalcaemia, hypophosphataemia, and nephrolithiasis. The following year she developed signs of bilateral nephrolithiasis. Calculi were passed following endoscopy and ureteral catherization. In 1964 symptoms reappeared on the left side, necessitating surgical intervention. An uneventful left nephrolithotomy was performed. There was a long history of hypertensive cardiovascular disease successfully treated with reserpine.

Other than for the stigmata of previous surgical intervention the physical examination was negative save for left flank tenderness. B.P. 140/85, pulse 90 , respiration 22 , temperature $101^{\circ} \mathrm{F}$; the urine, which had a specific gravity of 1.003, was negative for albumen, acetone, and reducing substances. There were 2-4 white cells and 1-2 red cells per high-power field. The B.U.N. was 28, Hct. 36, W.B.C. 16,200, Cl $105 \mathrm{mEq} . / \mathrm{L}$., K $4.5 \mathrm{mEq} . / \mathrm{L}$., $\mathrm{Na} 130 \mathrm{mEq} . / \mathrm{L}$., Ca $8.0 \mathrm{mg} . \%$ creatinine $3.8 \mathrm{mg} . \%$ Ureteral and renal calculi were observed on the left side by intravenous pyelography.

Therapy consisted of sulfisoxazole $1 \mathrm{gm}$. p.o. q.i.d., chloramphenicol $500 \mathrm{mg}$.

-Department of Anesthesiology, Albert Einstein College of Medicine, Bronx, New York.

Can. Anaes. Soc. J., vol. 13, no. 6, November, 1966 
p.o. q.4h., colistimethate sodium $75 \mathrm{mg}$. intramuscularly b.i.d., dextropropoxyphene $65 \mathrm{mg}$. p.o. q.4h. for pain, and acetylsalicylic acid $600 \mathrm{mg}$. q.4h. p.r.n. for elevations in temperature.

One week after admission the patient, now afebrile, was scheduled for an elective left uretero-nephrolithotomy. Premedication, with $100 \mathrm{mg}$. of pentobarbital and $0.4 \mathrm{mg}$. of atropine was administered intramuscularly one hour prior to surgery. Anaesthesia was induced with thiopental $100 \mathrm{mg}$. followed by a nitrous oxide, oxygen-curare sequence. The trachea was intubated with an $8.5 \mathrm{~mm}$. cuffed snow-white tube. Ventilation was controlled manually throughout the 1 hour and 45 minute operative procedure. A total of $30 \mathrm{mg}$. of curare was given during the first 15 minutes of anaesthesia. Fifty minutes after anaesthesia was established with a 7:3 nitrous-oxide-oxygen mixture, the arterial blood gas values were $\mathrm{P}_{\mathrm{a}} \mathrm{O}_{2} 116 \mathrm{~mm}$. $\mathrm{Hg}, \mathrm{P}_{\mathrm{a}} \mathrm{co}_{2} 13 \mathrm{~mm}$. $\mathrm{Hg}, \mathrm{pH}$ 7.63. At the termination of the operation apnoea persisted in spite of attempted curare reversal with $1.2 \mathrm{mg}$. of atropine and $5 \mathrm{mg}$. of neostigmine. The patient was transferred to the recovery room where she was mechanically ventilated with a Bird Mark 8 respirator. Stimulation of the ulnar nerve was indicative of a persistant non-depolarizing type of neuromuscular block (Fig. 1). This response was not altered by the intravenous administration of $10 \mathrm{mg}$. of edrophonium. Artificial ventilation was continued with 40 per cent oxygen for 2 hours, at which time the arterial $\mathrm{P}_{\mathrm{CO}_{2}}$ was $12 \mathrm{~mm}$. $\mathrm{Hg}, \mathrm{pH} 7.60$, and $\mathrm{P}_{\mathrm{a}} \mathrm{O}_{2} 375 \mathrm{~mm}$. Hg. Ventilation was decreased in an attempt to return the $\mathrm{PoO}_{2}$ to the normal range. Within one hour the $\mathrm{P}_{\mathrm{a}} \mathrm{Co}_{2}$ rose to $23 \mathrm{~mm}$. $\mathrm{Hg}$, the $\mathrm{pH}$ fell to 7.46, the $\mathrm{P}_{\mathrm{a}} \mathrm{O}_{2}$ was unchanged. At 2 P.M., four hours after termination of the operation, spontaneous respiration returned. The response to nerve stimulation was normal (Fig. 2). Spontaneous respiration, however, was inadequate, and there was clinical evidence of rapid fatigue of the respiratory musculature. Respiration was therefore assisted with the Bird ventilator. A careful review of the chart at this time disclosed the prior medication with colistin methanesulfonate (17 doses). Blood drawn for antibiotic levels at this time subsequently assayed at $8 \mu \mathrm{g}$. per cent. One gramme of calcium chloride was administered slowly with constant monitoring of the electrocardiogram. Several minutes later the respiration was adequate. The endotracheal tube was no longer tolerated and was removed. An uneventful recovery period followed; the patient was discharged on the tenth postoperative day.

\section{Discussion}

The neuromuscular blocking activity of colistin could have been predicted on the basis of its structure. Chemically, it is a polypeptide closely related to, if not identical with, the polymixins. ${ }^{15}$ Prolonged postoperative neuromuscular blockade has not until recently been a significant problem with any of these compounds. Because of their inherent toxicity their use has been almost completely limited to topical application and to oral administration for "sterilization" of the bowel. In both cases absorption is poor. The sodium salt of the methane sulfonate of colistin is less toxic than are the other polymixins. Its parenteral use, in cases of gram-negative infection, therefore, is becoming more frequent. Animal 


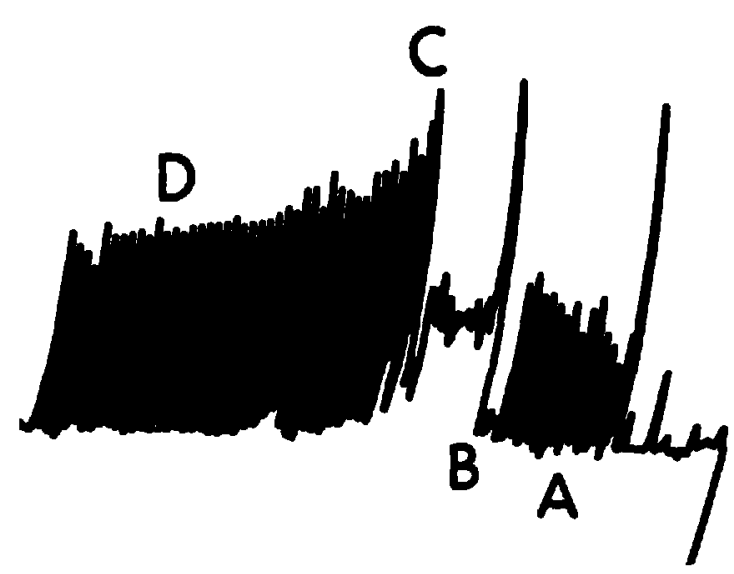

Figure 1. Response to ulnar nerve stimulation. A, $C$, and $D$, single repeative stimuli; $B$, tetanizing current. There is failure to sustain tentanus (B) and marked post-tetanic faciliation.

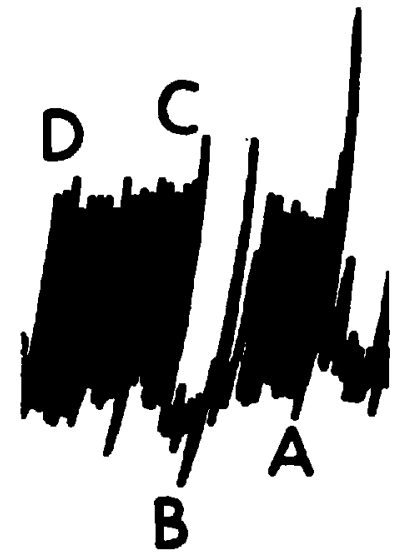

Ficure 2. Normal response to repeative stimulation (A, $C$, and ulnar nerve). Posttetanic facilitation is absent. Maintenance of tetanus (B) was not recorded due to a shift in the base line.

experimentation indicates that colistin is active in blocking at the myoneural junction whereas colistin methanesulfonate sodium is devoid of blocking actions. This lack of activity in vivo has been explained on the basis of its rapid elimination by the kidney. ${ }^{12}$ Since renal function was depressed in this patient, it was thought that her blood level may well have risen to "toxic levels." The blood assay of $8 \mu \mathrm{g}$. per cent was well within the normal therapeutic range.

Timmerman, Long, and Pittinger, ${ }^{16}$ using the rabbit sciatic nerve-gastronemius found that neomycin, streptomycin, dihydrostreptomycin, polymixin B, and kanamycin all produced neuromuscular blockade. This was subsequently confirmed by Sabawala and Dillon ${ }^{17}$ who employed human intercostal muscle-nerve preparations removed at thoracotomy. Streptomycin and neomycin appeared to be competitive blocking agents potentiated by ether and antagonized by neostigmine. Kanamycin and polymixin $B$ on the other hand appeared to be noncompetitive. Nevertheless, neostigmine-resistant blockade has been reported in man following istillation of neomycin. ${ }^{18}$ In 1948 Brownlee and Bushly ${ }^{19}$ described the neostigmine resistant blockade of aerosporin. The failure of neostigmine to reverse the blocking action of the polypeptide antibiotics was also noted by Adamson, Marshall, and Long. ${ }^{12}$ Since the neuromuscular blockade produced by these antibiotics is reversed with calcium chloride, Brazil and Corrado 20 likened the block to that produced by magnesium. More recently Kubikowski and Szeniawski, ${ }^{21}$ on the basis of electromyographic studies, expressed the belief that the antibiotic paralysis is biphasic. A short initial phase of competitive blockade is followed by a prolonged period of depolarization combined with calcium depletion. This would explain the neostigmine resistence and the reversal by calcium salts. 


\section{SUMMARY}

A case of prolonged postoperative neuromuscular blockade is described in a patient who had received the polysaccharide antibiotic colistin methanesulfonate preoperatively. The paralysis was neostigmine resistant but responded to administration of calcium chloride.

\section{RÉSUMÉ}

On rapporte un cas de blocage neuromusculaire prolongé chez un malade qui avait reçu l'antibiotique polysaccharide (colistiméthate) avant l'opération. La paralysie était résistante à la néostigmine mais l'administration de chlorure de calcium était efficace.

\section{REFERENCES}

1. Emery, E. R. J. Neuromuscular Blocking Properties of Antibiotics as a Cause of Postoperative Apnoea. Anaesthesia. 18: 57 (1963).

2. Prmgen, J. E. Respiratory Arrest Thought to be Due to Intraperitoneal Neomycin. Surgery. 40: 571 (1956).

3. Pittinger, C. B.; Long, J. D.; \& Miller, J. R. The Neuromuscular Blocking Action of Neomycin: A Concern of the Anesthesiologist. Anesth. \& Analg. Curr. Res. 37: 276 (1958).

4. MuLLETT, R. D. \& Keats, A. S. Apnea and Respiratory Insufficiency after Intraperitoneal Administration of Kanamycin. Surgery. 49:530 (1961).

5. Bush, G. H. Prolonged Neuromuscular Block Due to Intraperitoneal Streptomycin. Brit. Med. J. 1: 557 (1961).

6. FIsK, G. C. Respiratory Paralysis after a Large Dose of Streptomycin: Report of a Case. Brit. Med. J. I: 556 (1961).

7. Strchissiv, O.; Voloshm, D. C.; \& Alrard, C. A. Neurcmuscular Paralysis and Respiratory Arrest Caused by Intrapleural Neomycin. Med. Assoc. J. 81: 32 (1959).

8. Ream, C. R. Respiratory and Cardiac Arrest after Intravenous Administration of Kanamycin with Reversal of Toxic Effects by Neostigmine. Ann. Int. Med. 59: 384 (1963).

9. Ross, E. D. T.; Settle, J. A. D.; \& Telfer, A. B. M. Oral Neomycin: A Possible Anaesthetic Hazard. Brit. Med. J. 2: 1109 (1963).

10. Cooprr, E. A. \& Hanson, R. DE G. Oral Neomycin and Anaesthesia. Brit. Med. J. 2: 1527 (1963).

11. Marx, G. F.; Bennet, E. J.; \& Orkon, L. R. Oral Neomycin and Respiratory Failure. Canad. Anaesth. Soc. J. 12: 415 (1965).

12. Adamson, R. H.; Manshacr, F. N.; \& Lonc, J. P. Neuromuscular Blocking Properties of Various Polypeptide Antibiotics. Proc. Soc. Exper. Biol. \& Med. 105: 494 (1960).

13. Perkins, R. L. Apnea With Intramuscular Colistin Therapy. J. Amer. Med. Assoc. 190: 421 (1964).

14. Parusi, A. F.; \& Kaplan, M. H. Apnea during Treatment with Sodium Colistimethate. J. Amer. Med. Assoc. 194: 298 (1965).

15. Krantz, J. C. \& Carr, C. J. The Pharmacologic Principles of Medical Practice. Baltimore: Williams and Wilkins (1965), p. 119.

16. Timmerman, J. C.; Long, J. P.; \& Prrtinger, C. B. Neuromuscular Blocking Properties of Various Antibiotic Agents. Toxicol. App. Pharmacol. 1: 299 (1959).

17. Sabawla, P. B.; \& Dillon, J. B. The Action of Some Antibiotics on the Human Intercostal Nerve-Muscle Complex. Anesthesiology. 20: 659 (1959).

18. Kownacka, V. P. \& SerLin, O. Intraperitoneal Neomycin as a Cause of Apnea. Arch. Surg. $81: 838(1960)$.

19. Brownlaze, G. \& Bushly, S. R. Chemotherapy and Pharmacology of Aerosporin. Lancet. 1: 127 (1948).

20. Brazin, O. V. \& Conrado, A. P. The Curariform Action of Strephomycin. J. Pharmacol. Exper. Therap. 120: 452 (1957).

21. Kubirowsar, P. \& SzRentawsKa, $Z$. The Mechanism of Neuromuscular Blockade by Antibiotics. Arch. internat. pharmacodyn. 146: 549 (1963). 